\title{
MOTIVACE VĚČNÉHO NÁVRATU A PROBLÉM ČASU K článku J.-B. Gourinata
}

Věčný návrat má jistě své místo $\mathrm{v}$ inventárí filosofických témat, která jsou přesně vymezeným pojmovým problémem i obrazem působícím za hranicemi dané akademické disciplíny. Jean-Baptiste Gourinat vykládá ve svém článku dochované prameny, svědčící o zrození tohoto motivu ve stoické fyzice, aniž by přitom opomněl některé ohlasy stoické nauky, včetně pozdního stvoření výrazu ,věčný návrat“, jehož autorem je Friedrich Nietzsche. Následující řádky nenabízejí stejně podrobné filosofické ani filologické zkoumání; jejich cílem je stručnější připomenutí dvou obecnějších otázek, z nichž první nás vrací k motivaci tohoto zvláštního učení, druhá pak ke vztahu mezi věčným návratem a stoickým pojetím času.

Vize opakujících se kosmických zrození je motivována - a v jistém smyslu vynucena - tím, co bez dalšího komentáře shrnuje závěr Gourinatova článku: žádná komplexní živá bytost nemůže být podle stoiků věčná, at' už jde o individuální rostliny a živočichy, nebo živý svět jako celek. Kompozice všech těchto entit podléhá týmž zákonům, takže co platí pro části světa, platí i pro jeho stejně látkový celek. ${ }^{1}$ Svět čili kosmos je však jako všeobjímající celek dokonalý, jinými slovy úplný a božský, a jako takový nemůže prostě zaniknout. Co je úplné čili dokonalé, ale nemůže být „,věčně pořád“", tak musí být ve své rozvinuté podobě „,věčně znovu“. Na rozdíl od Platóna i Aristotela, pro něž je opakované rození náhradní, biologickou aproximací plné věčnosti (viz Symp. 208a-b; Leg. IV,721c; De an. II,4,415a26-b7), pro stoiky patří palingenesis čili nové rození

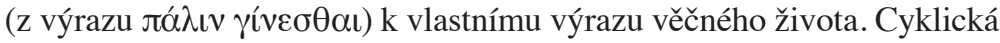

1 Český čtenář disponuje vynikajícím přehledem stoických textů na téma vzniku bohatě strukturovaného kosmu, které překládá a komentuje Filip Karfík, Předpoklady stoické kosmogonie, in: Reflexe, 18, 1998, str. 1-30 (přetištěno in: týž, Duše a svět. Devět studií z antické filosofie, Praha 2007, str. 150-184). Tato studie obsahuje též klíčové pasáže týkající se věčného návratu a je vhodným doplněním a rozšířením Gourinatova výkladu. V tomto stručném komentáři nebudu znovu reprodukovat pasáže, které v celku citují Karfík či Gourinat. Cituji naopak některé texty, na něž pouze odkazují nebo je parafrázují. Výjimkou je níže citovaná pasáž ze Seneky, kterou cituje v závěru svého výkladu Filip Karfík. 
geneze není z jejich hlediska nápodobou, nýbrž přímým výrazem vtělené dokonalosti, což dosvědčuje i pasáž z Diogena Laertského, v níž je shrnuto stoické užívání výrazu „kosmos“:

„Slova „kosmos“ užívají v trojím významu. Za prvé ve významu samého boha, který se vyznačuje zvláštní vlastností, odvozenou z celé

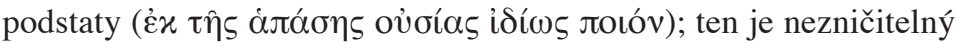
a nestvořený, sám jsa tvůrcem světového uspořádání ( $\delta \eta \mu \iota v 0 \gamma o ̀ s$

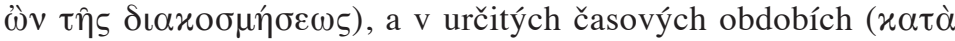

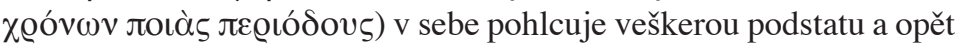
ji ze sebe plodí. Za druhé nazývají kosmem samo uspořádání nebeských těles a za třetí to, co je z obojího složeno. Kosmos je to, co

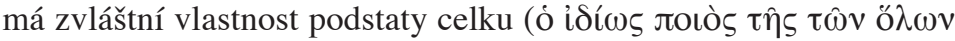
oủoías), neboli, jak praví Poseidónios v Základech učení o nebeských jevech, soustava z nebe (oủ@avós) a Země s bytostmi v ní se vyskytujícími, neboli soustava z bohů, lidí a všeho, co bylo kvůli nim vytvořeno. Nebe pak je nejkrajnější obvod, v němž má sídlo vše, co je božské."2

Citovaný text jasně odlišuje celek kosmu od částí, které v něm po určitý čas vyděleně existují a k nimž patří vedle nebeských těles i lidé, rozumné bytosti, „kvůli nimž“ je pestrý prrítomný svět vytvořen. Tato účelnost poukazuje $\mathrm{k}$ často diskutovanému motivu prožretelnosti, pro naše téma je však úžeji významná sama nepřevoditelnost celku na souhrn částí:

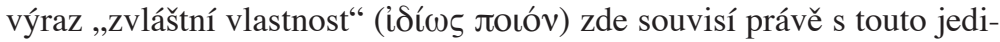
nečností a k jeho významu patří i to, že celek jako bůh, jenž je v silném smyslu věčný, je vlastní příčinou vzniku svých částí, z nichž se skládá kosmos v užším, ale i pestřejším smyslu strukturovaného světa s nebeskými tělesy a dalšími živými bytostmi. Důležité přitom je, že bez ohledu na to, $v$ jakém kvalitativním stavu jsou části vytvořeného světa, jeho prríčina, kterou je dokonalá, úplná a tedy niterně oživená podstata celku, zůstává neustále činná. Proměňují se však látkové nástroje, skrze něž působí, a také výsledné útvary, jež nabývají stále nižších podob, v nichž je původní život stále obtížněji rozpoznatelný (sestup od svižné periferie kosmu k jeho malátnému středu odpovídá u stoiků procesu stárnutí postupně tvořeného světa). Tato nedokonalost je zřejmě tím, co klade meze procesu dalšího tvoření, jehož směr se tak obrací a tvưrčí síla ohně začíná

2 Diogenés Laertios, Životy, názory a výroky proslulých filosofư, přel. A. Kolár, Pelhřimov $1995^{2}$, str. 296 (= DL VII,137-138). 
ze světa ustupovat. Zastavení celého procesu není myslitelné: k celku kosmu patří činnost, která prostupuje a udržuje všechny vytvořené části, jež nemohou existovat bez ní, zatímco ona bez nich ano. Svět, jenž má z hlediska dokonalosti svých částí podobně stupňovité uspořádání, jaké známe od Platóna či Aristotela, tak nabízí tvưrčí síle jakýsi žebřrík, po němž může vystoupat zpět do sebe sama. ${ }^{3}$

Krása pestře tvarovaného světa kolem nás, vytvořeného pro naši rozumovou potěchu, tak nemůže zániku př́ślušných tvarů zabránit o nic více, než může dokonalost naší tělesné stavby zabránit naší individuální smrti. Rozdíl je pouze ve způsobu, jímž se na rovině celku projevuje premisa vnitřního oživení kosmické látky, která nemůže ustat ve své činnosti a jako „něco“ též nemůže přejít v „nic“. ${ }^{4}$ Méně jasný je ovšem opačný pól celého procesu, v němž je svět pohlcen svou rozumnou duší, božským ohněm: proč vlastně nesetrvá čistý a myslící oheň ve svém nejlepším, a tím maximálně stejnorodém stavu? Z hlediska fyzikálního, a pro stoiky tedy i metafyzického, plyne odpověd’ z právě formulované premisy: myšlení čistého ohně je zároveň fyzikálním procesem, jenž př̀edpokládá vnitřní oživenost kosmické látky. Činnost čistého ohně tak nemůže spočívat jen v neměnném myšlení sebe sama bez intervence jiného předmětu, tedy v takovém myšlení, jímž Aristotelés obdařuje nelátkového prvního hybatele (Met. XII,9,1074b34). Každá látková činnost totiž předpokládá vzájemné působení částí látky; má-li si čistý oheň uchovat své napětí jako minimální podobu pohybu, jenž nemůže směřovat $\mathrm{k}$ neexistujícímu vnějšku, musí nutně docházet $\mathrm{k}$ jeho vnitřní diferenciaci. Oheň ve své čisté podobě je zřejmě „tvưrčíi“ proto,

3 Ke stoickému pojetí ,žebříku přírody“ viz B. Inwood, Ethics and Human Action in Early Stoicism, Oxford 1985, str. 20-27; T. Bénatouïl, Logos et scala naturae dans le stö̈cisme de Zénon et Cléanthe, in: Elenchos, 23, 2002, str. 297-331; V. Mikeš, Scala naturae u starých stoikü, in: L. Chvátal - V. Hušek (vyd.), „Přirozenost “ ve filosofi minulosti a současnosti, Brno 2008, str. 44-53; J. Wildberger, Beast or God? The Intermediate Status of Humans and the Physical Basis of the Stoic Scala Naturae, in: A. Alexandridis - L. Winkler-Horacek - M. Wild (vyd.), Mensch und Tier in der Antike, Wiesbaden 2008, str. 47-70.

4 Stranou ponechávám možnou (a případně velmi významnou) odlišnost názorů Kleantha a Chrysippa (druhé a třetí hlavy stoické školy) na důvody světového požá-

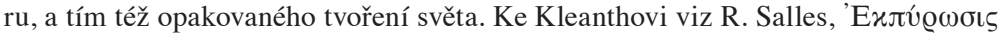
and the Goodness of God in Cleanthes, in: Phronesis, 50, 2005, str. 56-78; ke Chrysippovi J. Mansfeld, Providence and the Destruction of the Universe in Early Stoic Thought. With Some Remarks on the „Mysteries of Philosophy“, in: M. J. Vermaseren (vyd.), Studies in Hellenistic Religions, Leiden 1979, str. 129-188, a také R. Salles, Chrysippus on Conflagration and the Indestructibility of the Cosmos, in: týž (vyd.), God and Cosmos in Stoicism, Oxford 2009, str. 118-134. 
že nemá-li vnější předmět působení, musí vytvořit pasivnější pól své činnosti sám v sobě. Tento pól vyjadřuje první hnutí ohně ve směru světa, jehož utváření pak ukládá ohni nové meze, $v$ jejichž rámci se původní napětí ( $\tau$ óvos) tvưrčího ohně rozprostř̌e do celého nově utvořeného světa, s proměnlivou škálou činnosti a trpnosti v různých přírodních útvarech, včetně nás samých. ${ }^{5}$

Toto primárně fyzikální vysvětlení nám ovšem neříká, co skutečně dělá oheň ve stavu, v němž neexistuje svět ve druhém významu slova „kosmos“. Přítomnost napětí v neomezeně rozprostraněném ohni totiž nevypovídá nic o jeho činnosti. Jedním ze způsobů, jak tuto obtíž obejít, je vytčení obdoby mezi božským ohněm a myslí stoického mudrce. ${ }^{6}$ Stoikové častěji popisují sám okamžik přechodu do stavu moudrosti jako zásadní proměnu v oheň, ${ }^{7}$ některé texty s výslovnou etickou intencí se však věnují i přímé paralele obou stavů. Příkladem může být často uváděná pasáž ze Senekových Listi̊ Luciliovi:

„Jaký však bude život mudrce, bude-li bez přátel a bude uvržen do vězení, opuštěn v nějaké cizí zemi, zdržen dlouhou plavbou, vyvržen na opuštěném břehu?'Takový jako život Jovův, až se svět rozloží (cum resoluto mundo), bohové splynou $\mathrm{v}$ jediného, činnost přírody se na nějaký čas (paulisper) zastaví a on si odpočine, ponechán svým úvahám (adquiescit sibi cogitationibus).“8

Podle Seneky, jenž zřejmě parafrázuje Chrysippa, se čistý oheň soustř̌edí na své myšlenky v přestávce mezi zánikem světa a počátkem vznikání stejného světa $\mathrm{v}$ novém provedení. Již $\mathrm{v}$ antice se přitom objevuje názor, že takové líčení je zavádějící, nebot' z něj plyne, že božský princip

5 K fyzikálně i morálně zajímavé otázce, jak daleko sahá v rámci pasivního pólu přírody prozřetelná činnost boha čili tvůrčího ohně, viz T. Bénatouïl, How Industrious can Zeus be? The Extent and Objects of Divine Activity in Stoicism, in: R. Salles (vyd.), God and Cosmos in Stoicism, str. 23-45.

6 Výchozím rámcem této obdoby může být i srovnání světa a člověka; viz Plútarchos, Comm. not. 1077d: „Chrysippos říká, že Zeus a kosmos se podobají člo-

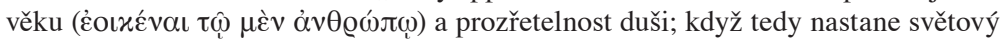

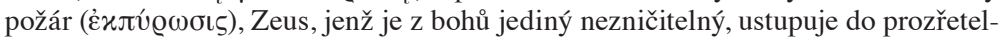

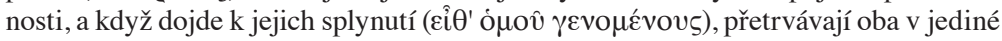
podstatě éteru.“

7 Viz texty, které uvádí R. Brouwer, The Stoic Sage: The Early Stoics on Wisdom, Sagehood and Socrates, Cambridge 2014, str. 76-77.

8 Seneca, Dopisy psané stoikem, přel. V. Bahník - B. Ryba, Praha 2018, str. 23 $(=$ Ep. IX,16). 
je po určitou dobu ve stavu nečinnosti. ${ }^{9}$ Možnou odpovědí je samožrejmě poukaz na to, že navzdory př́íslovci paulisper, jež běžně označuje chvíli odpočinku, myšlení není totéž jako nečinnost a Seneka může citovaného obrazu užít i díky již zmíněné totožnosti Jupiterovy mysli s prozřetelností. Výzva k nápodobě Diova osamělého uvažování umožňuje propojit kosmologii s etikou a toto propojení zůstává obousměrné: i v plně rozvinutém světě je božská mysl naším relevantním vzorem; ${ }^{10}$ v procesu rozvíjení světa je přitom předem zahrnut ohled prozřetelnosti k lidským bytostem, jež tvoří spolu s bohy společenství rozumových bytostí v rámci strukturovaného kosmu. ${ }^{11} \mathrm{Z}$ tohoto hlediska se rozvinutý, plně rozlišený svět jeví jako současně velkorysý a nutný dar myslícím, k moudrosti směřujícím bytostem: dar, který bude prozřetelnost kvủli jejich individuální nedokonalosti nucena opakovat.

Na metafyzické rovině má však námitka nečinnosti boha v intervalu mezi kosmickými cykly jinou váhu; připomíná nám totiž problematickou roli, kterou hraje v logice věčného návratu motiv času. I když platí, že myšlení je pro stoiky formou činnosti látkového rozumu, souvislost mezi průběhem této činnosti a stoickou teorií času je nanejvýš nejasná, a to tím více, že tato souvislost se týká i vztahu - či spíše napětí - mezi opakováním obsahu kosmických cyklů a stoickou teorií totožnosti. Problém totožnosti či míry možné odchylky v obsahu jednotlivých cyklů

9 Pro tuto námitku viz Cicero, De nat. deor. I,22, nebo Filón Alexandrijský, Aet. 83-84.

10 Viz například Epiktétos, Diss. III,13,7-8, překlad R. Kuthan: „Jako Zeus sám se sebou žije a spokojuje se sám se sebou a přemýšlí o způsobu své vlády a obírá se myšlenkami, které jsou ho hodny, právě tak i my máme umět hovořit k sobě samým, nikoho jiného nepotřebovat, zábavy nepostrádat; máme rozjímat o božském řízení

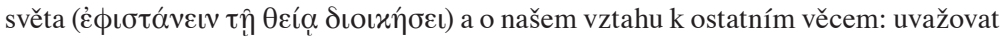
o tom, jak jsme se dříve chovali k tomu, co se nám přiházelo, a jak se chováme ted; a konečně o tom, které jsou to věci, jež nás stále ještě tísní, jak i tyto napravit, jak je odstranit; vyžadují-li některé z nich zdokonalení, zdokonalit je způsobem jim přiměřeným." Seneku i Epiktéta (stejně jako Chrysippa z poznámky 4) cituje a stručně komentuje A. A. Long, The Stoics on World-Conflagration and Everlasting Recurrence, in: R. H. Epp (vyd.), Southern Journal of Philosophy, 23, Suppl., Recovering the Stoics. Spindel Conference 1984, 1985, str. 23-24.

11 Ke stoické „kosmické obci“ jako společenství bohů a moudrých lidí viz např́íklad M. Schofield, The Stoic Idea of the City, Chicago 1999², str. 57-92; D. Obbink, The Stoic Sage in the Cosmic City, in: K. Ierodiakonou (vyd.), Topics in Stoic Philosophy, Oxford 1999, str. 178-195; K. M. Vogt, Law, Reason and the Cosmic City: Political Philosophy in the Early Stoa, Oxford 2008, str. 111-160; J. P. F. Wynne, God's Indifferents: Why Cicero's Stoic Jupiter Made the World, in: Apeiron, 45, 2012, str. 354-383. 
probírá Gourinat pod hlavičkou „problému numerické identity“, s odkazem na Órigenovo svědectví i moderní výklady Jonathana Barnese a Anthonyho Longa, kteří odlišují různé varianty „stejnosti“ individuí v jednotlivých cyklech. Gourinatův výklad zde netřeba reprodukovat; stačí připomenout klíčovou alternativu: „Jestliže se nějaké jsoucno zrodí znovu, postrádá pak jakékoli odlišnosti, nebo se nějak liší?" Pro naši úvahu je dobré vyjít od první čili „ortodoxní "možnosti, tedy od návratu naprosto totožných jedinců, o němž zřejmě mluví původní verze nauky připisovaná Zénónovi z Kitia. ${ }^{12}$ Ve spojení s otázkou času vede totiž ortodoxní verze mnohem názorněji (spíše než logičtěji) k pochybnosti o tom, zda je možné mluvit o mnohosti cyklů ve smyslu posloupnosti jednotlivých světů, které by vznikaly a zanikaly počitatelně jeden po druhém.

Důvodem této pochybnosti jsou nejasnosti týkající se stoického chápání času, které máme doloženo jen zlomkovitě a nejednoznačně. ${ }^{13}$ Pro nás důležitá otázka přitom zní, zda nám známé stoické definice času platí jen v rámci kosmu jako soustavy, v níž existují různě se pohybující nebeská tělesa (tedy v rámci druhého významu výrazu „kosmos“), či zda lze o čase mluvit i tam, kde existuje jediné, čistě stejnorodé těleso. První z těchto možností lze hájit na základě definic, které Chrysippovi prripisují Simplikios a Stobaios. Podle prvního z nich ,ze stoiků Zénón

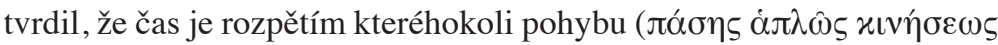

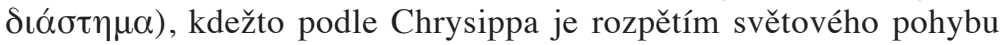

12 K rozdílu ortodoxní a heterodoxní podoby věčného návratu srv. M. J. White, Cosmic Cycles, Time, and Determinism, in: týž, Agency and Integrality. Philosophical Themes in the Ancient Discussions of Determinism and Responsibility, Dordrecht 1985, str. 173-214, a R. Salles, Determinism and Recurrence in Early Stoic Thought, in: Oxford Studies in Ancient Philosophy, 24, 2003, str. 253-272.

13 Pro hlavní prameny a shrnutí teoretických obtíží viz A. A. Long - D. Sedley, The Hellenistic Philosophers, Cambridge 1987, I, str. 304-308. Long a Sedley neuvádějí definici z Diogena Laertského VII,141, podle níž je netělesný čas ,,rozpětím

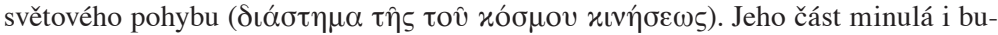
doucí je neomezená, část př́ítomná však omezená.“ Tato pasáž je částečně identická s níže diskutovanou definicí Chrysippovou. Následující poznámky se soustředí pouze na motivy úzce relevantní pro naše téma; zcela stranou ponechávám problém stoických idiomů vyjadřujících časové rozměry. Z širších výkladů stoického pojetí času viz alespoň V. Goldschmidt, Le système stö̈cien et l'idée de temps, Paris 1979; R. Sorabji, Time, Creation and the Continuum, London 1983, str. 17-32; M. Schofield, The Retrenchable Present, in: J. Barnes a M. Mignucci (vyd.), Matter and Metaphysics, Napoli 1988, str. 329-374; P. Tzamalikos, Origen and the Stoic View of Time, in: Journal of the History of Ideas, 52, 1991, str. 535-561; M. B. Papazian, Stoic Ontology and the Reality of Time, in: Ancient Philosophy, 19, 1999, str. 105-119. 


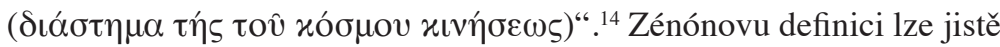
aplikovat na každý pohyb: pokud bychom se domnívali, že činnost ohně ve fázi jeho ,odpočinku“ nepřestává být pohybem, i tento pohyb se děje v čase, který je jím podmíněn. Už zde ale vyvstává možný problém: nic nenasvědčuje tomu, že by myslící oheň ve svém čistém stavu uchovával vzpomínku na předešlé světové cykly, které by takto v čase dále a dále počítal. Oheň obsahuje zárodky př́štího cyklu, které se rozvinou bez možné odchylky díky povaze ohně, kterou stoikové označují za prozřetelnost; nejde však o ,jízdní řád“", díky němuž by oheň odpočítával dobu do zahájení dalšího cyklu tvoření a poté kontroloval včasné dosažení jeho jednotlivých etap, a tím ověřoval, že časové odvíjení světa je stejné jako „minule“. Řečeno prostě: provází-li myšlení čistého ohně čas, nejde o čas ničeho jiného než tohoto myšlení sama, tedy čas, který neumíme vztáhnout $\mathrm{k}$ vnějším fyzikálním souřadnicím spjatým se strukturou světa.

Chrysippova definice se takovýmto úvahám o času mimo strukturovaný svět vyhýbá v případě, že redukci času na rozpětí pohybu kosmu vztáhneme ke druhému významu slova „kosmos“. V takovém případě lze o čase smysluplně mluvit natolik, nakolik provází pohyby v rámci strukturovaného světa, tedy v první řadě pohyby nebeských těles. Ve prospěch tohoto čtení lze uvést i pasáž ze Stobaia, podle níž „Chrysippos tvrdil, že čas je rozpětím pohybu, jímž se měří rychlost a pomalost ( $x \alpha \theta$ '

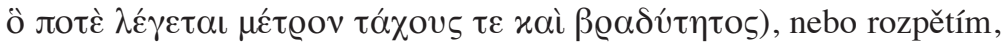

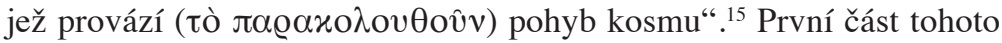
textu odkazuje nejsnáze k různé rychlosti nebeských těles, např́íklad Slunce a Měsíce. I dodatek, podle něhož se „každá věc“ pohybuje a existuje podle času, toto čtení podporuje, pokud se týká individuí v rámci strukturovaného kosmu. Vzápětí připojené Chrysippovo srovnání nekonečnosti času s nekonečností prázdna vyznívá podobně, nebot' prázdno existuje pouze kolem vymezeného světa, po jehož konci je pohlceno rozpínajícím se ohněm: o čase by mělo podle logiky tohoto srovnání platit totéž. ${ }^{16}$ Lze-li mluvit o existenci pro sebe sama myslícího ohně v čase,

\footnotetext{
14 Simplikios, In Arist. Cat. 350,15-16 Kalbfleisch.

15 Stobaios, Eclog. I,106,5-8.

16 Jakkoli jde o text, s nímž musíme vzhledem $\mathrm{k}$ jeho pojetí stvoření zacházet opatrně, stejným směrem ukazuje pasáž z Filóna Alexandrijského, Opif. V,26: Filón zde přejímá stoickou, či přesněji Chrysippovu definici času a dodává, že žádný pohyb - ve smyslu pohybu utvářené vnímatelné látky - nemohl nastat před vznikem věcí (v plurálu), které se pohybují, tedy před vznikem strukturovaného světa. Čas, uzavírá Filón, je tedy mladší než vzniklý kosmos, nebo nanejvýš stejně starý.
} 
jedná se o čas nesouměřitelný s časem, jenž vzniká až spolu s mnohostí pohybů $\mathrm{v}$ utvářeném kosmu.

V případě této nesouměřitelnosti, stejně jako tehdy, pokud by čas mimo strukturovaný svět neexistoval, čelíme problému, jak světy počítat $v$ čase, tedy jinak než jejich teoretickým rozlišením skrze přidělení abstraktního indexu, jenž by odlišoval nominálně různé, ale reálně neodlišitelné verze Sókrata či kterékoli další jednotliviny. Jde přitom o problém navozený fyzikální stránkou stoické teorie; naopak Gourinatem rovněž zmiňovaná pythagorejská verze věčného návratu se s ním vyrovnává snadněji, nebot' se týká navazujících cyklů definovaných „,velkým rokem“ čili opakováním určitého postavení nebeských těles. ${ }^{17}$ Časová trhlina spjatá s návratem veškeré látky do stavu čistého ohně takovou návaznost znemožňuje, a to už proto, že nelze říci, po jaké době se cyklus opakuje. Cykly tak nelze datovat, přesněji řečeno jejich hypotetické datování by nebylo dostupné lidské mysli. Výsledná situace má lehce fantastický nádech, jenž je vystižen posledním odstavcem Borgesova eseje Teorie cyklů, v němž je řeč mimo jiné o pythagorejcích, stoicích i Nietzscheho verzi věčného návratu:

„Na závěr jedna nejistota, tentokrát metafyzická. Pokud by se přijala Zarathustrova teze, nedaří se mi pochopit, jak to, že se dva identické procesy přestaly sdružovat $\mathrm{v}$ jeden. Stačí pouhá následnost, nikdy neprokázaná? Pokud neexistuje zvláštní archanděl, který by si vedl přehled, co to znamená, že procházíme cyklem třináct tisíc pět set čtrnáct, a ne prvním z řady nebo cyklem číslo tři sta dvacet dva umocněným dvěma tisíci? Nic pro praxi - což mysliteli neškodí. Nic pro inteligenci - a to je už vážné." ${ }^{18}$

K motivu mimosvětského pozorovatele lze jistě dodat, že ani on by nemohl opakované stavy světa počítat, protože žádný cyklus není v tomto schématu první. O něco přesnější je v tomto smyslu diagnóza této

17 Jde zřejmě o specificky pythagorejskou teorii; např́íklad Platón netvrdí, že by návrat planet do jejich postavení při vzniku světa implikoval začátek opakování toho, co se odehrává na zemském povrchu. K pythagorejské verzi známé díky Eudémovi viz D. E. Hahm, The Origins of Stoic Cosmology, Columbus 1977, str. 186, a G. Stamatellos, Plotinus and the Presocratics. A Philosophical Study of Presocratic Influences in Plotinus' Enneads, New York 2007, str. 130-131.

18 J. L. Borges, Teorie cyklư, in: týž, Další pátrání, Dějiny věčnosti, přel. M. Mašínová, Praha 2011, str. 347-348. 
situace z pera Bertranda Russella, jehož úvahou se ostatně Borges inspiruje a z větší části ji cituje v jiném ze svých esejů, nazvaném Kruhový čas:

„Mnoho autorů si představovalo, že dějiny jsou cyklické, že prrítomný stav světa, přesně takový, jaký je právě nyní, se dříve nebo později vrátí. Co povíme o této hypotéze z našeho hlediska? Budeme muset říci, že pozdější stav je numericky identický s dřívějším stavem, nemůžeme však říci, že se tento stav vyskytuje dvakrát, nebot' to by implikovalo systém datování, který tato hypotéza neumožňuje. Byla by to podobná situace, $\mathrm{v}$ jaké by byl člověk, který koná cestu kolem světa: neřekne, že výchozí a cílový bod jsou dva různé, ale navzájem si naprosto podobné body; řekne, že je to totéž místo. Hypotézu, že dějiny jsou cyklické, lze vyjádřit takto: vytvořte skupinu všech kvalit současných s nějakou danou kvalitou; $v$ určitých případech pak bude celek této skupiny předcházet sám sebe. Nebo: $v$ těchto případech předchází každá libovolně velká skupina současných kvalit samu sebe. Takovou hypotézu nelze považovat logicky za nemožnou, pokud říkáme, že se vyskytují pouze kvality. Abychom ji učinili nemožnou, museli bychom předpokládat okamžitý subjekt kvalit a tvrdit, že tento subjekt je identický sám se sebou nikoli díky svému charakteru, ale díky své časoprostorové pozici.“"19

Jinak řečeno: je-li vytvořený kosmos soustavou kvalit a celkově, jak

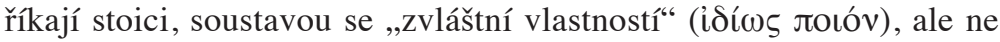
prostorově umístěnou podstatou, pak můžeme mluvit o jednotlivých cyklech, jež přitom nejsou řadou podstat v témže místě. Stále však neexistuje hledisko, z něhož bychom mohli tyto cykly vzájemně uspořádat - a tedy smysluplně odlišsit. Časové chápání ortodoxní verze věčného návratu je tak nemožné (přičemž každý posun k heterodoxnímu chápání, v němž se cykly nepatrně liší, je vykročením ze stoického rámce směrem k proměnlivým vlastnostem vázaným na určitou podstatu).

Gourinat se snaží tomuto problému vyhnout v oddíle 2.1, v němž rozlišuje mezi časem kruhovým, jenž nemá směr a neexistuje v něm začátek a konec, a časem periodickým, v němž jsou začátek a konec vyznačeny vzplanutím světa. K čemuž dodává: ,Jestliže je čas extenzí pohybu světa, pak jelikož během vzplanutí není svět, není ani čas. Čas světa tak nikdy

19 B. Russell, Zkoumání o smyslu a pravdivosti, Praha 1975, přel. J. Husák, str. 126; částečně cituje J. L. Borges, in: týž, Další pátrání, Dějiny věčnosti, str. 351. 
nespojí svůj konec se začátkem, nebot' mezi začátkem a koncem je ono přerušení, jímž je vzplanutí.“ Existuje tedy „nekonečně časů podobných tomu našemu, které našemu skutečně předcházejí nebo po něm následují “ ${ }^{20}{ }^{20}$ Toto vysvětlení nás však vrací $\mathrm{k}$ výše zdůrazněné otázce po časové či spíše nečasové povaze ,přerušení“ během existence čistého ohně, díky němuž nejde o spojení konce se začátkem, ale o ryzí opakování, jehož jednotlivé př́ípady nelze ani na základě pojmu periodického času odlišit. Námitka z pseudo-aristotelských Problému XVII,3,916a38-39 tak není vyvrácena: pokud se lidské dějiny cyklicky opakují, skutečně „nejsme oproti obyvatelům Tróje pozdější, ani oni nepředcházejí nám“ “. ${ }^{21}$

Problémy spjaté se sebe-identickou, a přece mnohonásobnou existencí přitom nejsou jen technicky zábavnou marginálií. Jak ukazuje Gourinat, stoikové si byli dobře vědomi obtíží, $\mathrm{k}$ nimž nauka o věčném návratu vede. Nejasnosti ohledně časové následnosti a rozlišitelnosti jednotlivých světů je proto nejlépe chápat jako cenu, kterou byli staří stoikové ochotni zaplatit za setrvání na svých základních principech. Otázka času nás tak vrací k motivaci takto sporného učení, které je důsledkem stoického chápání racionality člověka a racionality světa. Tato klíčová návaznost, zdůrazněná již v úvodu tohoto komentáře, je jasně shrnuta v dnes méně citované knize Victora Goldschmidta o stoickém systému a ideji času: stoikové chápou dění v celém kosmu jako výraz jednotné racionality, jež vylučuje ostré zlomy mezi nebeskými a zdejšími bytostmi, z nichž první by byly nesmrtelné a druhé smrtelné. Protože však nebeské sféry nemohou ztratit svou látkově určenou dokonalost, jež nepřipouští žádnou odchylku v jejich činnosti, obor nutnosti se musí rozšîrit z těchto sfér na celý svět: ani kolem nás se nyní nemůže nic dít jinak, než se děje. Pestrý svět kolem nás se i nadále liší od stavu nebeské oblasti, ale není jejím trvalým prostorovým protipólem. Čisté jednoduchosti, jež i v tomto

20 J.-B. Gourinat, Věčný návrat a periodický čas ve stoické filosofii, přel. J. Joseph, str. 109-123 v tomto čísle časopsisu.

21 Viz tamt., str. 118. Gourinat čte tuto pasáž jako příklad „kruhového“ pojetí, v němž se konec a začátek shodují. Text však lze chápat i jinak: žádný cyklus není první a žádný poslední - nahrazení kruhu ,periodickým“ časem, jenž do cyklu promítá odlišný konec a počátek, pak na konstatované neodlišitelnosti nic nemění. Srv. H. Hudson, A Response to A. A. Long's „The Stoics on World-Conflagration and Everlasting Recurrence“, in: Southern Journal of Philosophy, 28, 1990, str. 154: „Kruhové pojetí času zachraňuje stoiky před logickým sporem, přičemž numerickou identitu a nerozlišitelnost lze očekávat jako nejlepší možné důsledky neochvějného kauzálního determinismu a boží laskavosti a stoikům stačí jen říci, že jeden předmět je ve stejném místě ve stejném čase.“ 
schématu odpovídá nejzazší morální čistotě, tak lze dosáhnout až tehdy, když vyprší čas celého vnitřně rozlišeného světa, jenž však - jako jediná živá bytost svého druhu, obsahující všechnu existující látku - nemůže ani prostě zaniknout ani se znovu zrodit v jiné podobě. ${ }^{22}$

Karel Thein

22 K takto chápané motivaci učení o věčném návratu viz V. Goldschmidt, Le système stoïcien et l'idée de temps, str. 189-190. - Tento text vznikl za podpory projektu Kreativita a adaptabilita jako předpoklad úspěchu Evropy v propojeném světě reg. č.: CZ.02.1.01/0.0/0.0/16_019/0000734 financovaného z Evropského fondu pro regionální rozvoj. 